\title{
MORPHOLOGY AND POLLEN VIABILITY OF Lolium multiflorum Lam.
}

\author{
Morfologia e viabilidade polínica de Lolium multiflorum Lam.
}

\author{
Renata de Castro Nunes ${ }^{1}$, Fernanda de Oliveira Bustamante', Vânia Helena Techio², Andréa Mittelmann³
}

\begin{abstract}
Study and characterization of pollen grains are essential for different areas, especially taxonomy, genetic improvement, phylogeny, and paleobotany. As yet, there are no reports on pollen morphology of genotypes of naturalized Lolium multiflorum Lam., introduced cultivars or breeding populations, diploid or polyploid. Ten genotypes of annual ryegrass $(L$. multiflorum) were evaluated for the viability of pollen grains using propionic carmine and Alexander's stains, while morphology was assessed by the acetolysis technique. Measures of polar axis $(\mathrm{P})$, equatorial diameter $(\mathrm{E})$, exine thickness, and analysis of pollen grains were obtained by scanning electron microscopy (SEM). All genotypes showed high rate of pollen viability (> 89\%) for both stains. There were differences between genotypes in the following quantitative traits: polar axis, equatorial diameter, exine, endexine, ektexine, and P/E ratio. Pollen grains were characterized as small, monoporates, with circular and non-prominent apertures. In addition to helping distinction of pollen grains, morphometric differences can be used later to compare ploidy levels, thus assisting in breeding programs of the species.
\end{abstract}

Index terms: Scanning electron microscopy, ryegrass, acetolysis.

\section{RESUMO}

O estudo e a caracterização do grão de pólen são fundamentais para diferentes áreas, em especial, para a taxonomia, o melhoramento genético, a filogenia e a paleobotânica. Para genótipos de Lolium multiflorum Lam., naturalizados no Brasil, cultivares introduzidas ou populações de melhoramento, diploides e poliploides, não existem relatos sobre a caracterização morfopolínica. Nesse trabalho foram analisados dez gentótipos de azevém anual (L. multiflorum). A viabilidade dos grãos de pólen foi verificada por coloração com os corantes carmim propiônico e Alexander e a morfologia por meio da técnica de acetólise, sendo obtidas medidas do eixo polar (P), do diâmetro equatorial (E), e da espessura da exina, e análise dos grãos de pólen por microscopia eletrônica de varredura (MEV). Todos os genótipos avaliados apresentaram alta taxa de viabilidade polínica $(>89 \%)$ para os dois corantes utilizados. Houve diferença entre os genótipos para os caracteres quantitativos eixo polar, diâmetro equatorial na vista equatorial, exina, endoexina, ectoexina e razão P/E. Os grãos de pólen foram caracterizados como pequenos, monoaperturados, com abertura não proeminente e com âmbito circular. As diferenças morfométricas entre os grãos-de-pólen podem auxiliar na distinção entre os mesmos e, posteriormente, serem utilizadas para comparação entre os níveis de ploidia, auxiliando, assim, nos programas de melhoramento da espécie.

Termos para indexação: Microscopia de varredura, azevém, acetólise.

\section{(Received in march 21, 2012 and approved in april 25, 2012)}

\section{INTRODUCTION}

Lolium multiflorum Lam, known as annual ryegrass, belongs to the Poaceae family and is originally from the Mediterranean basin (southern Europe, northern Africa, and Asia Minor) from where it spread to Europe and North America. It had been already known in France in 1818 and in Switzerland in 1820, and was introduced in England in 1831 (NELSON et al., 1997). The species was first cultivated in Italy, so it is also called Italian ryegrass (L. italicum).

Ryegrass is widely cultivated in many temperate countries where climatic conditions are favorable for its development, as it is a cold hardy plant (MORAES, 1963;
ARAÚJO, 1967). In southern Brazil, ryegrass was probably introduced by Italian settlers in 1875 and is currently the largest temperate forage species grown to meet livestock feed demand in winter (ARAÚJO, 1978). Despite great interest in the forage and its large variability among and within populations (TCACENCO, 1989; OLIVEIRA et al., 1997; CORREA et al., 2007; MITTELMANN et al., 2010) little has been done in terms of genetic improvement in the country. In addition to productivity, other ryegrass features must be improved, such as seasonal distribution of forage yield with adjustments to meet periods of greatest need and different production systems (FONTANELLIELLI; FONTANELI, 2000).

\footnotetext{
'Universidade Federal de Lavras/UFLA - Departamento de Biologia/DBI - Lavras - MG - Brasil

${ }^{2}$ Universidade Federal de Lavras/UFLA - Departamento de Biologia/DBI - Cx. P. 3037 - 37200-000 - Lavras - MG - Brasil - vhtechio@gmail.com ${ }^{3}$ Empresa Brasileira de Pesquisa Agropecuária/Embrapa - Embrapa Gado de Leite - Juiz de Fora - MG - Brasil e Embrapa Clima Temperado Pelotas - RS - Brasil
}

Ciênc. agrotec., Lavras, v. 36, n. 2, p. 180 -188, mar./abr., 2012 
Recently, several tetraploid cultivars have been introduced in Brazil, with characteristics of agronomic interest, such as long cycle (MITTELMANN et al., 2004), but they have shown low capacity for natural re-seeding. Thus, offspring obtained from crossing diploid and tetraploid accessions of annual ryegrass are of interest for the breeding to the introduction of agronomic traits and the study of these offspring will lead to a better understanding of the reproductive process in these cultivars.

As yet, there are no reports on pollen morphology and viability in genotypes of naturalized $L$. multiflorum, introduced cultivars or breeding populations, diploid or polyploid. Thus, characterization of pollen grains is an important step for programs of genetic resource conservation and improvement, in order to complement basic studies of biological data that characterize genotypes. In addition, pollen viability data may correlate with meiotic abnormalities, assist in selection of genetic material, making it an additional tool in agriculture and biotechnology research.

Therefore, the objective of this work was to evaluate morphology and pollen viability of genotypes (parents and offspring) of L. multiflorum.

\section{MATERIAL AND METHODS}

Ten genotypes of annual ryegrass (L. multiflorum Lam) were evaluated (Table 1). The genotypes Comum, Barjumbo, INIA Titan and Avance are commercial cultivars available in Brazil, where samples for this study were derived from the Active Germplasm Bank of Ryegrass of Embrapa Gado de Leite/Embrapa Clima Temperado. The offspring resulted from crossing tetraploid mother plants and diploid fathers in a greenhouse, without emasculation. We used the 'chance hybrids' technique, in which a few plants of each cultivar are kept side by side and flowering is synchronized by cutting the earlier plant material. Only plants of the cultivar Barjumbo, Avance and INIA Titan were collected and they are the maternal plants of offspring.

Analysis of viability of pollen grains was estimated by their staining capacity by two colorimetric tests using $1 \%$ propionic carmine and Alexander's stain. In propionic carmine tests, red-colored pollen grains were considered viable while those unstained were deemed inviable. Using Alexander's stain, which contains malachite green and acid fuchsin, inviable pollen grains (aborted) stain green while viable pollen grains (not aborted) stain purple. In our tests, we evaluated 10 slides per genotype and 100 pollen grains per slide.

To analyze the morphology of pollen grains immediately after anthesis, anthers were collected, fixed in Carnoy (ethanol: propionic acid, 3:1), and stored at $-20^{\circ} \mathrm{C}$ until time of use. Slides were prepared according to the Erdtman acetolytic method (1952). Then we evaluated five slides per genotype and measured polar axis $(\mathrm{P})$, equatorial diameter $(\mathrm{E})$, and exine thickness in 10 pollen grains per slide. The measurements were performed with software Image Tool 3:00 UTHSCA(The University of Texas Health Science Center in San Antonio) within seven days after acetolysis, in order to avoid changes in morphology and size of pollen grains. We defined $\mathrm{P} / \mathrm{E}$ ratios to classify pollen types according to Punt et al. (1999). Size of pollen grains was determined by measuring the polar axis, based on the terminology by Punt et al. (1999). Photomicrographs of pollen grains were obtained with a Nikon microscope from images captured by a FDX 35 camera connected to a microcomputer.

Table 1 - Genotypes of L. multiflorum.

\begin{tabular}{ccc}
\hline Genotypes & Origin & Expected ploidy \\
\hline Comum & Local population & $2 \mathrm{x}$ \\
Avance & Introduced cultivar & $4 \mathrm{x}$ \\
Barjumbo & Introduced cultivar & $4 \mathrm{x}$ \\
INIA Titan & Introduced cultivar & $4 \mathrm{x}$ \\
A41 & INIA Titan x Comum & $3 \mathrm{x}$ \\
A42 & INIA Titan x Comum & $3 \mathrm{x}$ \\
A44 & INIA Titan x Comum & $3 \mathrm{x}$ \\
A45 & Avance $x$ Comum & $3 \mathrm{x}$ \\
A47 & Avance $x$ Comum & $3 \mathrm{x}$ \\
ABARP & Barjumbo $x$ Comum & $3 \mathrm{x}$ \\
\hline
\end{tabular}

Ciênc. agrotec., Lavras, v. 36, n. 2, p. 180 -188, mar./abr., 2012 
For analysis of scanning electron microscopy (SEM), anthers were prepared according to the standard protocol of the Laboratory of Electron Microscopy and Ultrastructural Analysis (LME) of Federal University of Lavras (UFLA). Inflorescences were washed three times for 10 minutes in cacodylate buffer and post-fixed in osmium tetroxide for 1 hour at room temperature. They were then washed three times, dehydrated in acetone gradient $(25 \%$, $50 \%, 75 \%, 90 \%$, and $100 \%$ for 10 minutes each). Next, the pollen grains were taken to a critical point dryer (CDP 030) and to a sputter coater (SCD 050), and were then analyzed by SEM-LEO EVO40.

Quantitative data were submitted to the analysis of variance and the Scott and Knott test $(\mathrm{p}<0.05)$. Pollen viability data were obtained by two methods: variation among genotypes within colorimetric test, and variation among colorimetric tests within each genotype. The analyses were performed with Sisvar program (FERREIRA, 2003).

\section{RESULTS AND DISCUSSION}

All genotypes showed high rate of pollen viability (> 89\%), regardless of the dye used for testing (Table 2 and Figure 1). Analysis of dyes within each genotype showed that Comum, A44, Avance, A45, and ABARP had no significant differences $(\mathrm{p}<0.05)$ in viability with neither Alexander's stain nor propionic carmine. However, differences were found ( $p>0.05)$ in the other genotypes (INIA Titan, A41, A42, A47 and Barjumbo).

Table 2 - Viability of pollen grains using colorimetric tests with propionic carmine and Alexander's stain in genotypes of L. mutiflorum.

\begin{tabular}{ccc}
\hline Genotypes & Carmine propionic (\%) & Alexander's stain (\%) \\
\hline Comum & $96.1 \mathrm{cA}$ & $93.4 \mathrm{bA}$ \\
INIA Titan & $99.3 \mathrm{~dB}$ & $97.5 \mathrm{dA}$ \\
A41 & $90.9 \mathrm{aA}$ & $94.7 \mathrm{cB}$ \\
A42 & $89.6 \mathrm{aA}$ & $93.2 \mathrm{bB}$ \\
A44 & $90.5 \mathrm{aA}$ & $90.4 \mathrm{aA}$ \\
Avance & $93.9 \mathrm{bA}$ & $95.0 \mathrm{cA}$ \\
A45 & $92.0 \mathrm{bA}$ & $92.9 \mathrm{bA}$ \\
A47 & $93.3 \mathrm{bA}$ & $97.2 \mathrm{~dB}$ \\
Barjumbo & $91.0 \mathrm{aA}$ & $95.7 \mathrm{cB}$ \\
ABARP & $93.6 \mathrm{bA}$ & $94.7 \mathrm{cA}$ \\
Means & 93.02 & 94.40 \\
\hline
\end{tabular}

Different lowercase letters in the column: significant difference by Scott and Knott test ( $p<0.05)$. Different capital letters in the line: significant difference by Scott and Knott test $(\mathrm{p}<0.05)$.
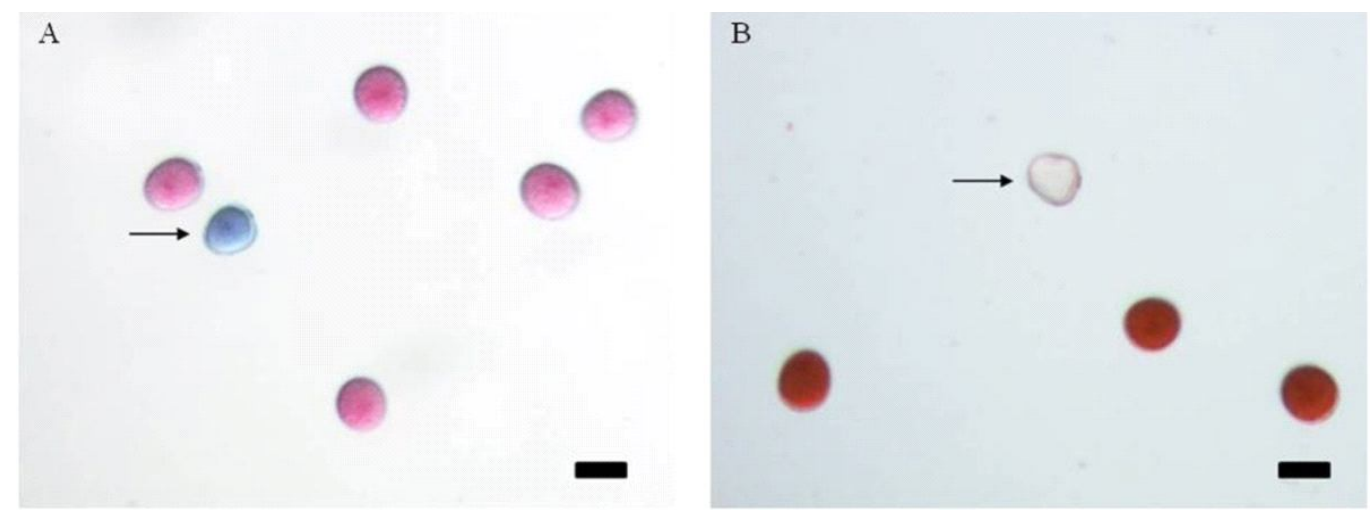

Figure 1 - Pollen grains of L. multiflorum stained with Alexander's stain (A) and propionic carmine (B). The arrow indicates inviable pollen grains. $\mathrm{Bar}=50 \mu \mathrm{m}$.

Ciênc. agrotec., Lavras, v. 36, n. 2, p. 180 -188, mar./abr., 2012 
The percentage of pollen viability ranged from $89.6 \%$ (A42) to $99.3 \%$ (INIA Titan) with an average of 93.02\% with propionic carmine, while rates with Alexander's stain ranged from $90.4 \%$ (A44) to $97.5 \%$ (INIA Titan) with an average of $94.4 \%$.

Viability rates estimated with propionic carmine showed that offspring A42, A44, and A41 (89.6\%, 90.5\%, $90.9 \%$, respectively) showed lower viability $(\mathrm{p}<0.05)$ than both parents INIA Titan (99.3\%) and Comum (96.1\%). A45 and A47 offspring (92.0\%, 93.3\%, respectively) and their parent Avance (93.9\%) had equivalent rates, although offspring showed lower rates $(\mathrm{p}<0.05)$ than parent Comum (96.1\%). Parent Avance (mean 93.9\%) showed a significant difference $(\mathrm{p}<0.05)$ in pollen viability when compared with Comum diploid (96.1\%). Barjumbo tetraploid $(91.0 \%)$ and Comum diploid $(96.1 \%)$ showed significant differences at $5 \%$ probability in their ABARP offspring (93.6\%) (Table 2).

In tests using Alexander's stain, only A44 offspring $(90.4 \%)$ showed lower viability $(\mathrm{p}<0.05)$ than both parents Comum (93.4\%) and INIA Titan (97.5\%). A44, A42, and A41 offspring (90.4\%, 93.2\%, and 94.7\%, respectively) showed differences between them ( $\mathrm{p}<0.05)$, as well as lower viability than parent INIA Titan (97.5\%). However, when compared with parent Comum (93.4\%) only A44 (90.4\%) and A41 (94.7\%) offspring showed significant differences ( $\mathrm{p}<0.05)$. In the crossing between Avance (tetraploid) x Comum diploid, only A47 offspring $(97.2 \%)$ had higher mean $(\mathrm{p}<0.05)$ than both parents, while A45 offspring (92.9\%) only differed from tetraploid parent Avance (95\%), showing a lower mean ( $\mathrm{p}<0.05)$. ABARP offspring $(94.7 \%)$ exceeded the viability of the diploid parent (93.4\%) but did not differ from Barjumbo tetraploid parent $(95.7 \%)(\mathrm{p}<0.05)$.

Viability rates were deemed high for all genotypes (parents and offspring). Offspring definitely showed fertilization potential, and thus can be incorporated into breeding programs, as effectiveness of crossing depends on very fertile pollen donors. The high rate of functional pollen in these genotypes may be associated with meiotic regularity and regular collection timings (8:30 am-10:00 am) when anther dehiscence begins, implying that viability reaches its maximum.

The results suggest non-triploid offspring, as the viability rate of pollen grains was high. However, this information can only be confirmed by counting chromosomes and assessing the meiotic behavior. Meiotic studies have been accomplished on the species and showed a regular process with formation of seven ring bivalents (KLEIJER, 1984; JAUHAR, 1975; TECHIO et al., 2010)

Differences in viability among genotypes can be explained by the considerable variation in loss of pollen viability between individuals of a species and between samples of the same individual (TECHIO et al., 2006). Pollen viability may vary greatly throughout its development. During flower opening pollen grains must be perfectly viable, as their viability and fertilization efficiency generally decrease as time progresses (SOUZA et al., 2002).

As manifestation of genotypes occurs through male-female gamete contribution, high pollen viability increases the possibility of forming different allele combinations, and ultimately, to the genetic variability (SOUZA et al., 2002). Thus, rates of pollen viability can be used to indicate the most favorable crossings.

Furthermore, pollen viability should be adequate to ensure seed production. In order to be widely used in production systems, offspring must produce a large numbers of viable seeds to meet the demand for extensive grazing areas. Thus, production of fertile pollen grains is absolutely necessary (PAIVA, 2006).

Studies using acetocarmine $1 \%$ in 52 genotypes of Triticale, an intergeneric hybrid originated from crossing between tetraploid wheat and diploid rye, showed that the average percentage of viable pollen grains in the genotypes ranged from $68.6 \%$ to $98.8 \%$. These values are considered high among genetically distinct genotypes (ZANOTTO et al., 2009). Acetocarmine $1 \%$ and propionic carmine $1 \%$ are widely used in routine analysis; however, they may be inadequate for some species, as thick exine of pollen grains can hamper dye penetration.

Measurements showed that all genotypes had pollen grains with polar axis $(\mathrm{P})$ smaller than equatorial diameters $(\mathrm{E})$, so that $\mathrm{P} / \mathrm{E}$ ratios of genotypes Comum, $\mathrm{A} 42$, and A45 ranged from 0.9058 to $0.9078 \mu \mathrm{m}$. Pollen grains were classified as oblate spheroid, according to the classification proposed by Punt et al. (1999). The genotypes A41, A44, A47, ABARP, INIA Titan, Avance and Barjumbo showed a range of variation of $0.8384-0.8736 \mu \mathrm{m}$ and oblate pollen grains (Figure 2). This difference was statistically confirmed by the Scott-Knott test ( $p<0.05$ ) (Table 3 ). We can, thus, infer morphological differences between pollen grains only detected by measurements (Figure 3 ). This variation within a species can be explained by the harmomegathic process, in which pollen grains change shape to accommodate variation in the cytoplasm volume caused by changes in hydration, which may reflect in the morphology assessment. 



Figure 2 - Polar and equatorial view of acetolyzed pollen grains of L. multiflorum genotypes (A) Comum, (B) Avance, (C) Barjumbo, (D) INIA Titan, (E) A41, (F) A42, (G) A44, (H) A45, (I) A47, (J) ABARP. Oblate spheroid: Comum (A), A42 (F), and A45 (H); Sub-oblate: the others. Bar=10 $\mu \mathrm{m}$. 
Table 3 - Means values (in $\mu \mathrm{m}$ ) of exine layers, polar axis, P/E ratios, and scope of pollen genotypes of $L$ multiflorum.

\begin{tabular}{ccccccc}
\hline Genotypes & Ektexine & Endoexine & Exine & Polar axis (P) & Rations P/E & Scope \\
\hline A44 & $1.06 \mathrm{~A}$ & $1.31 \mathrm{~B}$ & 2.38 & $29.01 \mathrm{~b}$ & $0.83 \mathrm{a}$ & Circular \\
ABARP & $1.28 \mathrm{~A}$ & $1.63 \mathrm{~B}$ & 2.92 & $36.78 \mathrm{e}$ & $0.84 \mathrm{a}$ & Circular \\
Barjumbo & $1.12 \mathrm{~A}$ & $1.39 \mathrm{~B}$ & 2.51 & $33.35 \mathrm{~d}$ & $0.86 \mathrm{a}$ & Circular \\
A47 & $1.14 \mathrm{~A}$ & $1.32 \mathrm{~B}$ & 2.47 & $30.15 \mathrm{c}$ & $0.86 \mathrm{a}$ & Circular \\
A41 & $1.14 \mathrm{~A}$ & $1.19 \mathrm{~A}$ & 2.33 & $30.12 \mathrm{c}$ & $0.87 \mathrm{a}$ & Circular \\
Avance & $1.09 \mathrm{~A}$ & $1.63 \mathrm{~B}$ & 2.73 & $31.10 \mathrm{c}$ & $0.87 \mathrm{a}$ & Circular \\
INIA Titan & $0.93 \mathrm{~A}$ & $1.41 \mathrm{~B}$ & 2.35 & $29.97 \mathrm{c}$ & $0.87 \mathrm{a}$ & Circular \\
A42 & $1.24 \mathrm{~A}$ & $1.27 \mathrm{~A}$ & 2.51 & $26.01 \mathrm{a}$ & $0.90 \mathrm{~b}$ & Circular \\
Comum & $1.18 \mathrm{~A}$ & $1.32 \mathrm{~B}$ & 2.51 & $26.73 \mathrm{a}$ & $0.90 \mathrm{~b}$ & Circular \\
A45 & $1.10 \mathrm{~A}$ & $1.44 \mathrm{~B}$ & 2.54 & $34.34 \mathrm{~d}$ & $0.90 \mathrm{~b}$ & Circular \\
\hline
\end{tabular}

Means followed by same letter in columns do not differ statistically by Scott and Knott test ( $p<0.05)$. Means followed by same letter in rows do not differ statistically by Scott and Knott test $(\mathrm{p}<0.05)$.

The genotypes Comum, INIA Titan, Avance, Barjumbo, A44, A45, A47, and ABARPhad thicker endexine (mean: $1.43 \mu \mathrm{m}$ ) than ektexine (mean: $1.11 \mu \mathrm{m}$ ). Only the genotypes A41 and A42 showed no significant differences ( $p$ $<0.05$ ) in ektexine and endexine measures (Table 3). According to Muller (1979), exine structure is related to protection, harmomegathic process, and reserve. In the past, it was suggested that electrostatic forces could be directly related to the outermost layer of the exine. Chaloner (1986) suggested that smooth pollen grains would lose their charge more quickly to achieve the same charge as the stigma. Galati and Rosenfeld (1998) reported that exine surfaces are electrically charged in the same way, as they have sporopollenin. This would cause mutual repulsion and enhanced pollen discharge, which could be considered a competitive advantage in fertilization. Moreover, exine thickness is directly related to staining, as thicker exines hamper dye penetration. This may lead to incorrect assessments on unviability and reduce the efficiency of responses provided by colorimetric tests.

In relation to the polar axis, a characteristic that determines the size of pollen grains, all genotypes were characterized as small, however we found significant differences $(\mathrm{p}<0.05)$ between genotypes. ABARP had the largest size (36.78 $\mu \mathrm{m})$, A44, INIA Titan, A41, A47, Avance, Barjumbo, A45 had intermediate values (29.01, 29.97, 30.12, $30.15,31.10,33.35,34.34 \mu \mathrm{m}$, respectively), and A42 and Comum had the smallest values (26.01 and $26.73 \mu \mathrm{m}$, respectively) (Table 3 ).

Number and size of pollen grains definitely influence competition, as these factors determine the area occupied on the stigma surface. To successfully reproduce, plants must disperse their resources appropriately to improve pollen grain size (small), germination capacity, and pollen tube growth (TEJASWINI, 2002). Considering this characteristic, Comum diploid and A42 offspring showed the best dispersion, as they were the smallest genotypes.

A negative correlation between pollen grain size and pollen tube length was reported in the family Caryophyllaceae. This suggests that it is more advantageous for a plant to produce a large number of small pollen grains than a small number of large grains, as small grains have a greater ability to compete (ability to germinate and produce large pollen tubes), which increases the reproductive adaptability (TEJASWINI, 2002).

Morphometric differences between genotypes can help distinguish them, and then be used to compare the levels of ploidy. This comparison may be based on the phenomenon gigas, in which plants with high ploidy levels are generally stronger and have larger stomata, flowers, pollen grains, and fruits when compared with plants of the same species showing lower ploidy level (SILVA et al., 2000; SCHIFINO-WITTMANN, 2004; CAMPOS et al., 2009).

Based on scanning electron microscopy (SEM) analysis, pollen grains were characterized as monoporates (a single pore), with circular and non-prominent apertures (Figure 3). Colpi are apertures with thin exine, where the pollen tube will emerge during fertilization (MIRANDA; ANDRADE, 1990). A great number of colpi increases the chances of successful emergence of the pollen tube, and consequently increasing the fertilization of egg cells. Thus, the number of colpi is an important feature for evolutionary inference. According to Miranda and Andrade (1990), pollen grains with only one aperture are more primitive than those with three apertures. 

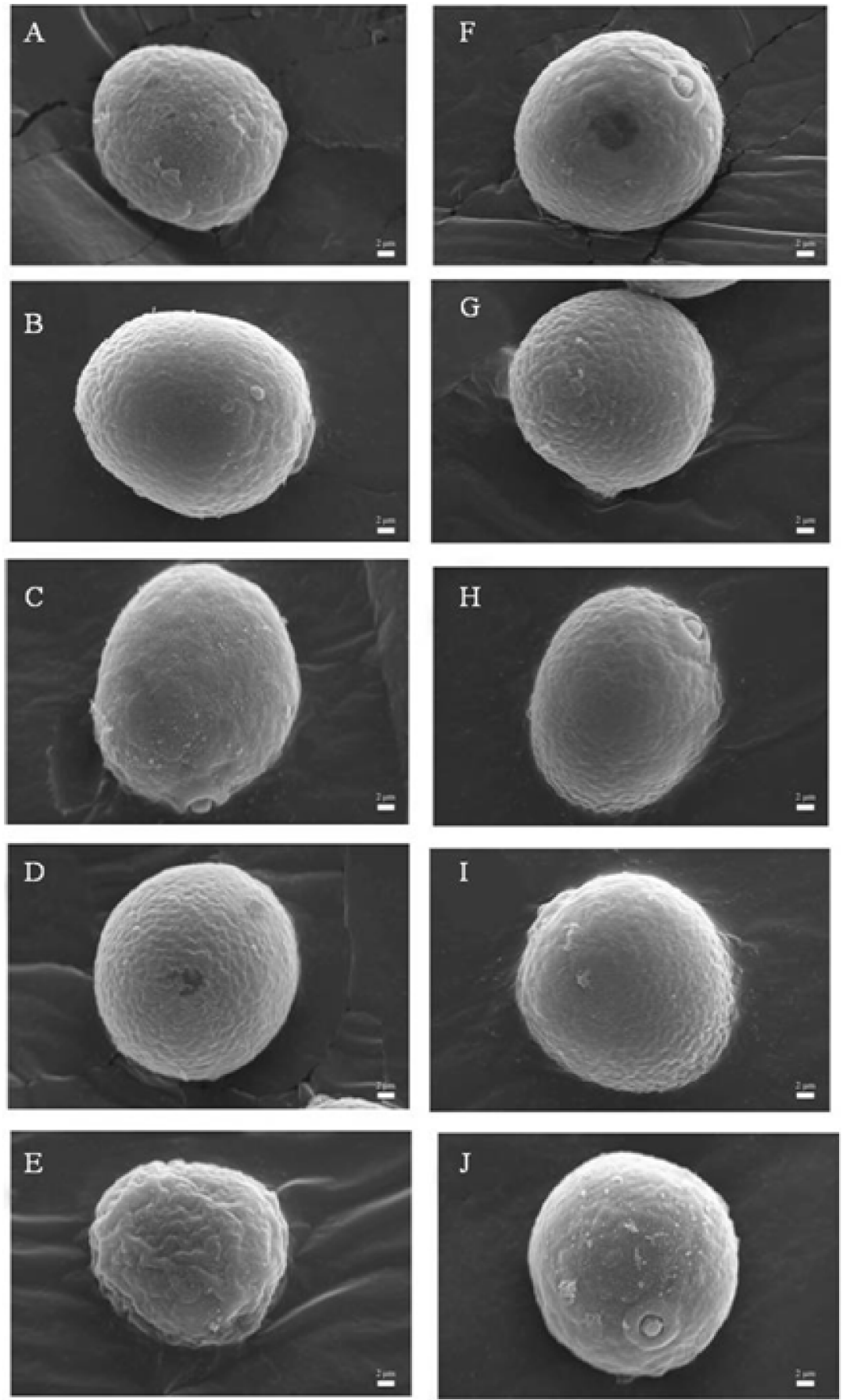

Figure 3 - Pollen grains of L. multiflorum Lam in SEM: (A) Comum, (B) Avance, (C) Barjumbo, (D) INIATitan, (E) A41, (F) A42, (G) A44, (H) A45, (I) A47, (J) ABARP. Bar = $2 \mu \mathrm{m}$. 
Given the characteristics presented here, pollen morphology can be useful in taxonomic and evolutionary studies of the genus Lolium.

\section{CONCLUSIONS}

The genotypes of $L$. multiflorum showed high rates of pollen viability. Pollen grains were characterized as small, monoporates with circular and non-prominent apertures and there were differences between genotypes in the quantitative traits.

In addition to helping distinction of pollen grains, morphometric differences can be used later to compare ploidy levels, thus assisting in breeding programs of the species.

\section{ACKNOWLEDGEMENTS}

The authors thank to Conselho Nacional de Desenvolvimento Científico e Tecnológico- CNPq, for financial support to the research and to Fundação de Amparo à Pesquisa do Estado de Minas Gerais - FAPEMIG for scholarship to the first author.

To professor Eduardo Alves (Laboratório de Microscopia Eletrônica e Análise Ultraestrutural da UFLA) by contributions in the analysis of electron microscopy.

\section{REFERENCES}

ARAÚJO, A.A. Forrageiras para ceifa. Porto Alegre: Sulina, 1967. 154p.

ARAÚJO, A.A. Forrageiras para ceifa: capineiras, fenação e ensilagem. Porto Alegre: Sulina, 1978. 196p.

CAMPOS, J.M.S. et al. In vitro induction of hexaploid plants from triploid hybrids of Pennisetum purpureum and Pennisetum glancum. Plant Breeding. Berlin, v.128, p.101-104, 2009.

CHALONER, W.G. Electrostatic forces in insect pollination and their significance in exine ornament. In: BLACKMORE S.; FERGUSON I.K. Pollen and Spores. Form and Function. London: Academic Press, 1986, v.12, p.103-108.

CORREA, B. O. et al. Caracteres agronômicos em populações locais de azevém no sul do Brasil. Magistra. Cruz das Almas, v.19, n.4, p. 274-282, 2007.

ERDTMAN, V. Pollen morphology and plant taxonomy: angiosperms. Stockholm: Almqvist \& Wilsell, 1952. 539p.

FERREIRA, D.F. 2003. Sisvar®. Versão 4.6 (Build 61); Universidade Federal de Lavras, Brasil.
FONTANELI, R. S.; FONTANELI, R. S. Subsídio ao planejamento forrageiro para produção de leite em pastagens durante o ano todo. In: FONTANELI, R. S.; DURR, J. W.; FONTANELI, R. S. (Ed.) Sistema de produção de leite, Passo Fundo: Universidade de Passo Fundo, 2000. p. 59-84.

GALATI, B.G.; ROSENFELD, S. The pollen development in Ceiba insignis (Kunth) Gibbs \& Semir ex Chorisia speciosa St. Hil. (Bombaeaceae). Phytomorphology, Delhi, v.48, p.121-130, 1998.

JAUHAR, P. P. Chromosome relationship between Lolium and Festuca. Chromosoma, Berlin, v. 52, p. 103$121,1975$.

KLEIJER, G. Cytogenetic studies of crosses between Lolium multiflorum Lam. and Festuca arundinacea Schreb. The parents and the F1 hybrids. Zeitschrift für Pflanzenzüchtung, v. 93, p. 1-92, 1984.

MIRANDA, M.M.B.; ANDRADE, T.A.P. Fundamentos de palinologia. Fortaleza: UFC, 1990. 99p.

MITELMANN, A. et al. Avaliação de populações de azevém quanto à produção de forragem. Juiz de Fora: Embrapa Gado de Leite; Bagé: Embrapa Pecuária Sul, 2004. 12 p. (Embrapa Gado de Leite/Boletim de Pesquisa, 15).

MITELMANN, A. et al . Caracterização agronômica de populações locais de azevém na região sul do Brasil. Ciência Rural, Santa Maria, v.40, n. 12, p.2527-2533, 2010.

MORAES, Y.J.B. Cultura do azevém (Lolium multiflorum). In: ASSOCIAÇÃO GABRIELENSE DE MELHORAMENTOE RENOVAÇÃO DEPASTAGENS, 1963, São Gabriel. Anuário... São Gabriel: Associação Gabrielense de Melhoramento e Renovação de Pastagens, 1963. p.18-21.

MULLER J. Form and function in angiosperm pollen. Annals of the Missouri Botanical Garden, St. Louis, v.66, n.4, p.593-632, 1979.

NELSON, L.R.; PHILLIPS, T.D.; WATSON, C.E. Plant breeding for improved production in annual ryegrass: In: ROUQUETTE, F.M.; NELSON, L.R. Ecology, production, and management of Lolium for forage in the USA. Madison: Crop Science Society of America, 1997, v.3, p.1-14. 
OLIVEIRA, J.A. et al Genetic diversity of westerwold ryegrass landraces collected in Northwest Spain.

Genetic Resources and Crop Evolution, Dordrecht,v.44, p.479-487, 1997.

PAIVA, E.A.A. Meiose em híbridos hexaploides de Capim-Elefante e Milheto. 2006. 53 p. Dissertação (Mestrado em Genética e Melhoraramento de Plantas) Universidade Federal de Lavras, Lavras, MG.

PUNT, W. et al. Glossary of pollen and spore terminology. 1999. Avaliable in: <http: www.biol.ruu.nl/ $\sim$ palaeo/glossary/glos-int.htm>. Access em: 10 jan. 2009.

SCHIFINO-WITTMANN, M.T. Poliploidia e seu impacto na origem e evolução das plantas silvestres e cultivadas. Revista Brasileira Agrociência, Pelotas, v.10, n.2, p.151157. 2004.

SILVA, P.A.K.X.M.; CALLEGARI-JACKES, S.;

ZANETTINI, M.H.B. Induction and identifcation of polyploids in Cattleya intermedia Lind. (Orchidaceae) by in vitro techniques. Ciência Rural, Santa Maria, v.30, n.1, p.105-111, jan./fev. 2000.

SOUZA, M.M.; PEREIRA, T.N.S.; MARTINS, E.R. Microsporogênese e microgametogênese associadas ao tamanho do botão floral e da antera, e viabilidade polínica em maracujá amarelo (Passiflora edulis f. flavicarpa Degener). Ciência e Agrotecnologia, Lavras, v.26, n.6, p.1209-1217, 2002.

TCACENCO, F.A. Comparação de cultivares de azevém anual em Lages, Estado de Santa Catarina. Pesquisa Agropecuária Brasileira, Brasília, v.24, p.157-163, 1989.

TECHIO, V.H. et al. Viabilidade dos grãos de pólen de acessos de capim-elefante, milheto e híbridos interespecíficos (capim-elefante x milheto). Acta Scientiarum Biological Science, Maringá, v.28, n.1, p.712, jan./mar. 2006.

TECHIO, V. H. et al. Meiotic and mitotic behaviour of B chromosomes of ryegrass. Ciência rural, v. 40, p. 83-88, 2010.

TEJASWINI. Variability of pollen grain features: a plant strategy to maximize reproductive fitness in two species of Dianthus? Sexual Plant Reproduction, Oklahoma, v.14. p.347-353, 2002.

ZANOTTO, M. et al. Viabilidade polínica como seleção assistida no programa de melhoramento genético de Triticale. Ciência e Agrotecnologia, Lavras, v.33, Edição Especial, p.2078-2082, 2009. 